\title{
エチレンジアミン浴よりの銅メッキ
}

乾忠 孝* 細川邦典* ・尾崎邦夫*

\section{Electrodeposition of Copper from Ethylene-diamine Bath}

Tadayoshi INUI*, Kunisuke HOSOKAWA* and Kunio OZAKI*

Investigations were made on the formation of chelate by the reaction between cupric ion and ethylene diamine (En), and the effect of $\mathrm{pH}$ on the structure of chelates.

The following results were obtained.

1) The chelate compound (CuEn) $)^{2+}$ was formed by the reaction between En and cupric ion in the $\mathrm{pH}$ range of 3.5 5.5 and the compound $\left(\mathrm{CuEn}_{2}\right)^{2+}$ was formed in the range of above 6.0. However, in the range of 5.5 6.0, the both complex ions, $(\mathrm{CuEn})^{2+}$ and $\left(\mathrm{CuEn}_{2}\right)^{2+}$, were formed.

2) Bright deposit of copper was obtained on steel with good adhesion from $\left(\mathrm{CuEn}_{2}\right)^{2+}$ chelate solution.

The optimum condition of the electrolysis was as follows.

\begin{tabular}{|c|c|}
\hline $\mathrm{CuSO}_{4} \cdot 5 \mathrm{H}_{2} \mathrm{O} \cdots \cdots \cdots \cdots \cdot 75 \sim 125 \mathrm{~g} / \mathrm{l}$ & 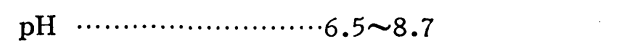 \\
\hline En $\cdots \cdots \cdots \cdots \cdots \cdots \cdots \cdots \cdots \cdots \cdots+65 \mathrm{~g} / l$ & Temperature $\cdots \cdots \cdots \cdot \cdots \cdot 10 \sim 50^{\circ} \mathrm{C}$ \\
\hline $\mathrm{Na}_{2} \mathrm{SO}_{4} \cdot 10 \mathrm{H}_{2} \mathrm{O} \cdot \cdots \cdots \cdots \cdots \cdot \ldots+\mathrm{g} / l$ & Cathodic current density $\cdots \cdots 1.5 \sim 2.5 \mathrm{amp} . / \mathrm{dm}^{2}$ \\
\hline
\end{tabular}

The current efficieney under the above condition was above $95 \%$.

\section{1. 藉}

シフン錯塩浴に代わる無毒性メッキ浴が最近とりあげ られているが, フミン銅錯塩浴もその一つである。とく にェチレンジフミン (以下 En と略記) は安価で, アン モニアに比べて揮発性が小さく, 各種メッキ金属と安定 なキレートを形成して良好なメッキ浴をつくることがで きる。これらのうち亜鉛, ニッケルについては先に報告 したので, ${ }^{1), 2)}$ 今回は銅についてその検討を試みた。En を用いた銅メッキについては N.V. Osetrova ${ }^{3)}$ や N.V. Gudin“) らのソ連に括ける研究があるが，電解に適した $\mathrm{pH}$ 範囲,電流密度など不明確な点が多い。したがって, まず各 $\mathrm{pH}$ 領域で存在するキレートの形を決定し, 電解 に適した $\mathrm{pH}$ 範囲, 電流密度を広く調へ, En の効果を 検討したので,ここに報告する。

\section{2. 実 ·験}

2-1 銅一En キレートの構造 および安定度について 水溶液中に打いて $\mathrm{Cu}^{2+}$ と En とからなるキレートの 組成および安定度については, J. Bjerrum ${ }^{5)} ら の$ 研究

*九州工業大学 (北九州市戸畑区仙水町)

The Kyushu Institute of Technology
で, $\left[\mathrm{CuEn}_{2}\right]^{2+}$ の組成のカチオンを生成し, $\log \mathrm{k}_{1}=$ 10.72, $\log k_{2}=9.31$ (ただし, $\log k_{1}, \log k_{2}$ は第 1 段 扣よび第 2 段の生成定数)であると報告されている。ま た，固体および水溶液中に括いて $\left[\mathrm{CuEn}_{3}\right]^{2+}$ の生成も あるが、これは容易に $\left[\mathrm{CuEn}_{2}\right]^{2+}$ と En 解離すると

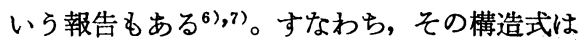

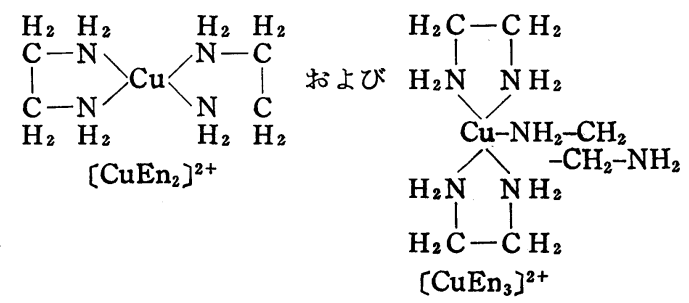

で, $\left[\mathrm{CuEn}_{3}\right]^{2+}$ に扔いては, 第 3 番目の En が1つの アミノ基で $\mathrm{Cu}$ 原子に配位しているため, その結合が弱 く容易に解離するといわれている。さらに低 $\mathrm{pH}$ 域では $[\mathrm{CuEn}]^{2+}$ の生成も当然あると考えられる。したがって メッキに大きな影響を拈よぼす $\mathrm{pH}$ の変化によって，錯 イオンの形がどのように変わるか確認するため, 光度計 法による測定を行なった。測定は，島津一ボッシュロムス ペクトロニック20で行ない, 銅化合物としては硫酸銅, En は無水 En を用い， pH 調整は硫酸で行なった。試 


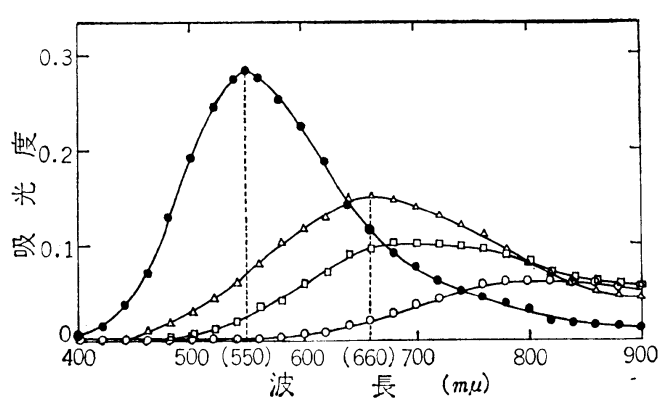

$\mathrm{Ccu}^{2+}=0.005 \mathrm{~mol} / \mathrm{l}$

$\mathrm{CEn}: \mathrm{CCu}^{2}+2: 1 \quad \triangle 1: 1 \quad \square \quad 1: 2 \bigcirc 0: 1$

第 1 図吸収曲線 $\mathrm{A}$

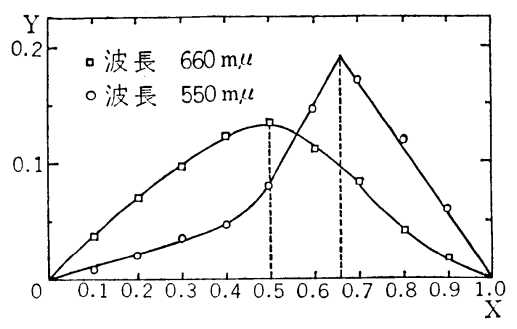

全溶算浱度 $0.01 \mathrm{~mol} / /$

$\mathrm{X}=\mathrm{CEn} /\left(\mathrm{CEn}+\mathrm{CCu}^{2+}\right) \quad \mathrm{Y}=$ (全吸光度 $)-\left(\mathrm{Cu}^{2+}\right.$ の吸光度 $)$

第2図連続変化法 $\mathrm{A}$

薬はすべて特級試薬をそのまま用いた。硫酸銅に対して いろいろな割合で En を配合して調製した溶液の吸収曲 線は第 1 図の通りで, 配合比 $1^{* 1}$ の溶液では $660 \mathrm{~m} \mu$, 配合比 2 の溶液では $550 \mathrm{~m} \mu$ に顕著な吸収極大がみられ る。この 2 つの波長で Job の連続変化法を試みた結果 は第 2 図の通りで, 明らかに $660 \mathrm{~m} \mu$ の吸収極大は「 $\mathrm{Cu}$ $\mathrm{En}]^{2+}$ とよるものであり, $550 \mathrm{~m} \mu$ の吸収極大は $\left[\mathrm{CuEn}_{2}\right]^{2+}$ によるものであることがわかる。

硫酸銅に対して En を過剩に配合した溶液の色は $\mathrm{pH}$ 3.5 までは淡青色, $\mathrm{pH} 3.5$ 以上では濃青色, さらに $\mathrm{pH}$ 6.5 以上ではすみれ色を呈する。そこで, 配合比 $3, \mathrm{pH}$ 3.5，5.2，9.0 の各溶液で吸収曲線をとってみると，第 3 図のように, 第 1 図とほぼ同じょうな形となり, pH 3.5 の溶液ではキレートが生成せず， pH 5.2 の溶液で は $[\mathrm{CuEn}]^{2+}$ が, $\mathrm{pH} 9.0$ では $\left[\mathrm{CuEn}_{2}\right]^{2+}$ が生成して いることがうかがわれる。

つぎに配合比 3 の溶液で $\mathrm{pH}$ を変えた場合の吸収をみ た結果は第 4 図の通りで, 波長 $660 \mathrm{~m} \mu$ では $\mathrm{pH} 3.5$ を 超えると次第に吸収が増加し, $\mathrm{pH} 5.1$ で極大に達して 再び城少し, pH 6.0 以上では一定値に達する。波長 550

*1 配合比はすべて全銅 $\mathrm{mol}$ 濃度飞対する全 $\mathrm{En} \mathrm{mol}$ 濃度の割合すなわち $\mathrm{C}_{\mathrm{En}} / \mathrm{C}_{\mathrm{cu}}{ }^{2+}$ の值で表わす。

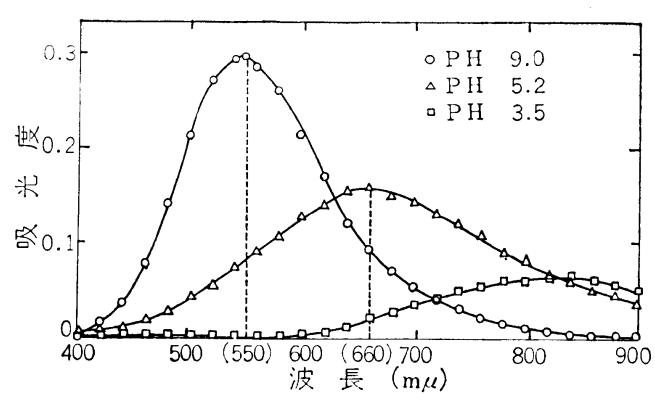

$\mathrm{CCu}^{2+}=0.005 \mathrm{~mol} / \mathrm{C} \quad \mathrm{CEn}: \mathrm{CCu}^{2+}=3: 1$ $\square \mathrm{Cu}^{2+}$ のみ

第3图吸収曲線 B

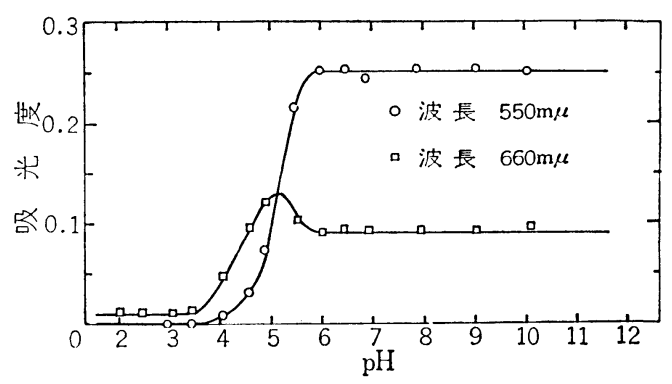

$\mathrm{CEn}: \mathrm{CCu}^{2+}=3: 1, \quad \mathrm{CCu}^{2+}=0.004 \mathrm{~mol} / l$

第 4 图吸収曲線 C（吸光度に括よほすす $\mathrm{pH}$ 影響）

$\mathrm{m} \mu$ では, 吸収は $\mathrm{pH} 4.0$ 以上で増加をはじめ, $\mathrm{pH} 6.0$ 以上で一定値に達する。この結果は, $\mathrm{pH}$ 上年によって まず, [CuEn $]^{2+}$ が生成し, pH 5.0 6.0で [CuEn $]^{2+}$ から $\left[\mathrm{CuEn}_{2}\right]^{2+}$ への移行があり, $\mathrm{pH} 6.0$ 以上で $[\mathrm{Cu}$ $\left.\mathrm{En}_{2}\right]^{2+}$ が安定になることを表わしている。この結果を さらに詳紐に確認寸るため, $\mathrm{pH} 5.0,5.5,7.5,10.5$ で連続変化法を行なってみると第 5 図 ((1) (4)) のよ らになり, pH 5.0 では $[\mathrm{CuEn}]^{2+}, \mathrm{pH} 5.5$ では $[\mathrm{Cu}$ $\mathrm{En}]^{2+}$ と $\left[\mathrm{CuEn}_{2}\right]^{2+}, \mathrm{pH} 7.5$ 护よび 10.5 では $[\mathrm{Cu}$ $\left.\mathrm{En}_{2}\right]^{2+}$ が存在し, $\mathrm{pH} 10.5$ でも $\left[\mathrm{CuEn}_{3}\right]^{2+}$ は確認さ れなかった。

以上の結果から, 結局, $\mathrm{pH}$ 変化によって, 銅一Enキ レートは第1表 のように変わることがわかった。

上の結果は $\mathrm{pH} 5.5$ では, $\left[\mathrm{CuEn}_{2}\right]^{2+}$ キレートがほ ぼ完全に生成するという G.A. Carlson らの $\mathrm{pH}$ 滴定に よる結果 (7) と一致している。

\section{2-2 分極曲線}

キレートの溶解度扣よび予備実験の結果から, En の 配合比を 2 以上にした, 全銅イオン濃度 $0.4 \mathrm{~mol} / l$ 前後 の溶液がメッキに適することがわかったので、 $\mathrm{CuSO}_{4}$ ・ $5 \mathrm{H}_{2} \mathrm{O} 100 \mathrm{~g} / l(0.40 \mathrm{~mol})$, En $50 \mathrm{~g} / l(0.83 \mathrm{~mol})$ の溶液 について $\mathrm{pH}$ を変えたるの, 酸性硫酸銅電解液およびア ルカリシアン電解液の分極曲線を, それぞれ定電位法に 


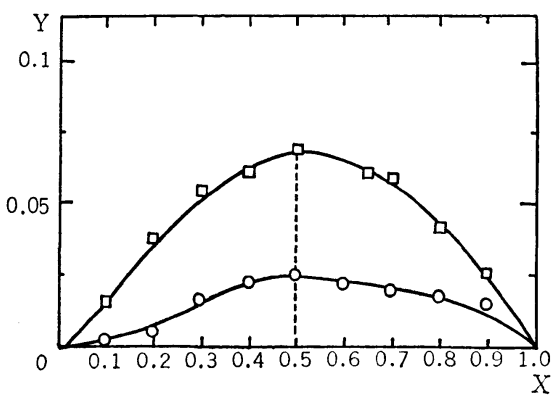

(1) $\mathrm{PH}=5.0$

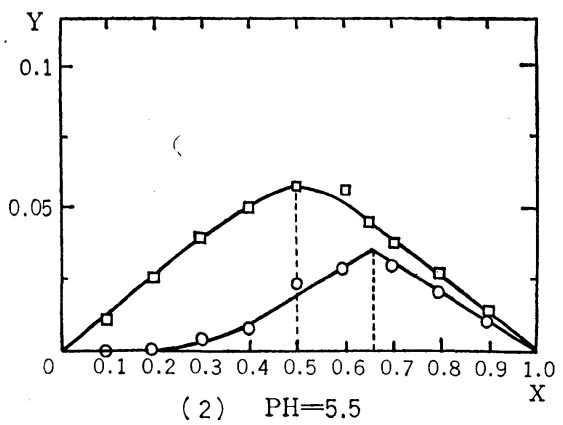

全溶質港度 $0.01 \mathrm{~mol} / / \mathrm{l}$ $\mathrm{X}=\mathrm{CEn} /\left(\mathrm{CEn}+\mathrm{CCu}^{2+}\right)$

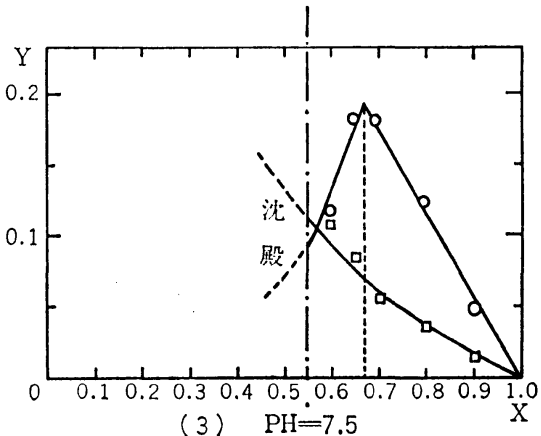

(3) $\mathrm{PH}=7.5$

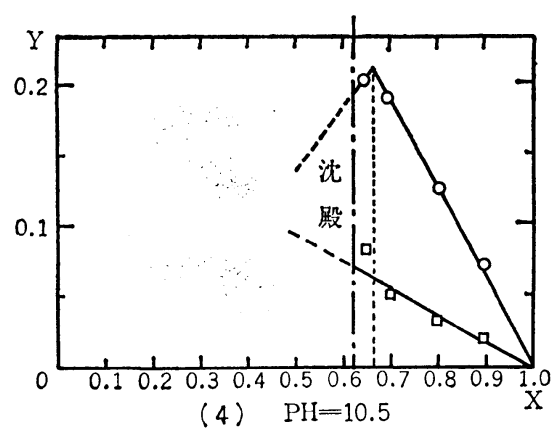

口 波長 $660 \mathrm{~m} \mu \quad \bigcirc$ 波長 $550 \mathrm{~m} \mu$

第5図連続変化法 B

より測定した。測定は, 自動加電圧装置付島津ポテンシ オスタット PSI型, 横河 X-Y レコーダ PRO 12型を 用いて，陽極，陰極ともバフ研摩した電解銅板で行なっ た。結果は第 6 図 の通りで, 銅一En 電解夜では $\mathrm{pH}$ の上䄯とともに分極が增すが， $\mathrm{pH} 11.6$ でも，フルカリ シアン電解液に比べと分極の度合いは小さい。

著者らがさきに行なった亜鉛 一En電解液の研究 ${ }^{1)}$ は塩化物電解夜を用いた方が溶解度が大きく, 良好な亜 鉛電着物が得られたので，塩化銅を用い，塩酸で $\mathrm{pH}$ 調 整を行なった銅一En 電解液について, 硫酸銅を用いた 場合と同じように分極曲線をとってみた。結果は第 7 図 の通りで，第6図とほぼ同様の傾向を示すが，pH 6.0 $\sim 8.5$, 電流密度 $2 \mathrm{~A} / \mathrm{dm}^{2}$ に怙ける析出電位が, 塩化物 電解液に打いては，拈よそ540 620 mV であるのに対 乙, 硫酸塩電解液に沶いては 780 850 mV とかなり大 である。しかしながら，光度計法による結果（第 1 表）

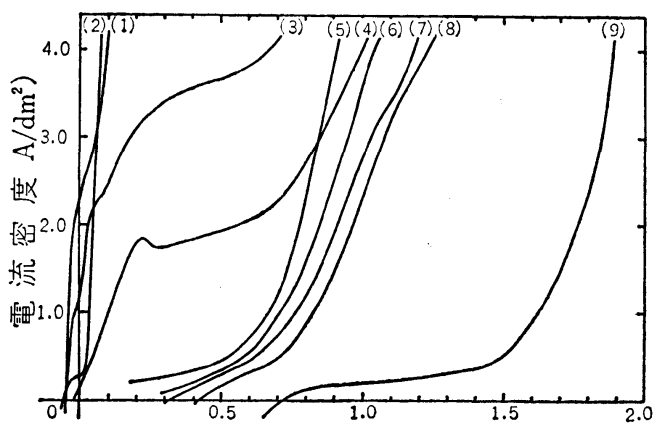

析出電位 (V.vs S.C.E.)

電位走查速度 $100 \mathrm{mV} / \mathrm{min}$ (1) 酸性硫酸銅浴 $\left(\mathrm{CuSO}_{4} \cdot 5 \mathrm{H}_{2} \mathrm{O} 200 \mathrm{~g} / \mathrm{l}, \mathrm{H}_{2} \mathrm{SO}_{4} 50 \mathrm{~g} / \mathrm{l}\right)$ (2) $\mathrm{CuSO}_{4} \cdot 5 \mathrm{H}_{2} \mathrm{O} 100 \mathrm{~g} / l$ (8) (8) $\mathrm{Cu}-\mathrm{En}$ 浴 $\left(\mathrm{CuSO}_{4} \cdot 5 \mathrm{H}_{2} \mathrm{O}\right.$ $100 \mathrm{~g} / l$, En $50 \mathrm{~g} / l, \mathrm{Na}_{2} \mathrm{SO}_{4} \cdot 10 \mathrm{H}_{2} \mathrm{O} 50 \mathrm{~g} / l$, $\left.\left(\mathrm{NH}_{4}\right)_{2} \mathrm{SO}_{4} 50 \mathrm{~g} / l\right)$ (3) $\mathrm{pH}=3.0 \quad$ (4) $\mathrm{pH}=4.0 \quad$ (6) $\mathrm{pH}=6.0 \quad$ (6) $\mathrm{pH}=8.5$ (7) $\mathrm{pH}$ -9.5 (8) $\mathrm{pH}=11.6$ (9) アルカリシフン浴 $(\mathrm{CuCN} 65 \mathrm{~g} / l$, $\mathrm{NaCN} 80 \mathrm{~g} / l$ )

第 6 図分極曲線 A（銅塩として硫酸銅を用いた場合）

第 1 表 $\mathrm{pH}$ 変化による銅-En キレートの構造変化

\begin{tabular}{c|c|c|c|c}
\hline \hline $\mathrm{pH}$ & 3.5 以下 & $3.5 \sim 5.0$ & $5.0 \sim 6.0$ & 6.0 以上 \\
\hline キレートの組成 & キレートは生成せす & {$[\mathrm{CuEn}]^{2+}$} & {$[\mathrm{CuEn}]^{2+}+[\mathrm{CuEn}]^{2+}$} & {$\left[\mathrm{CuEn}_{2}\right]^{2+}$} \\
\hline
\end{tabular}




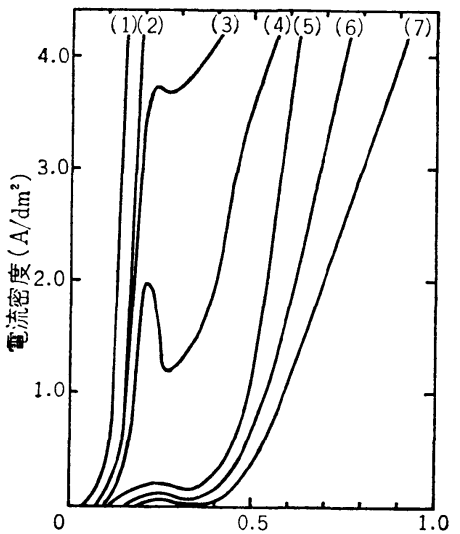

析出電位 (V.vs.S.C.E.)

電位走查迶度 $100 \mathrm{mV} / \mathrm{min}$.

(1) $\mathrm{CuCl}_{2} \cdot 2 \mathrm{H}_{2} \mathrm{O} 70 \mathrm{~g} / l, \quad$ (2) (7) $\mathrm{Cu}$-En浴 $\left(\mathrm{CuCl}_{2} \cdot 2 \mathrm{H}_{2} \mathrm{O}\right.$ $70 \mathrm{~g} / l$, En $50 \mathrm{~g} / l, \mathrm{Na}_{2} \mathrm{SO}_{4} \cdot 10 \mathrm{H}_{2} \mathrm{O} 50 \mathrm{~g} / l$, $\left(\mathrm{NH}_{4}\right)_{2} \mathrm{SO}_{4}$ $50 \mathrm{~g} / l$ ) (2) $\mathrm{pH}=0.4$ (3) $\mathrm{pH}=3.3 \quad$ (4) $\mathrm{pH}=4.5 \quad$ (5) $\mathrm{pH}=6.0$ (6) $\mathrm{pH}=8.5$ (7) $\mathrm{pH}=11.9$

第 7 図分極曲線（銅塩として塩化銅を用いた場合）

および塩化銅を用いて吸収を測定した H. B. Jonassen ら8) の結果からみて, pH 6.0 ８.5 に打けるキレート は, 用いる銅塩のアニオンの種類に関係なく, 両者とも $\left[\mathrm{CuEn}_{2}\right]^{2+}$ であるので，キレートよりの 銅析出に際し て大きな過電圧を必要とすることは，このキレートが安 定であることを示している。

\section{2-3 電解液の作成およひ最良メッキ条件の検討}

硫酸銅に En を $\mathrm{mol}$ 比で 2 倍以上加えた溶液では, 平衡電位, 析出電位とも負方向に移り, この溶液に鉄を 浸七キしても鉄と銅との置換反応が起こらず，鋼上に良 好なる銅メッキが得られる。予備実験の結果では $\mathrm{pH} 7.0$ 前後の電解液で，軟鋼上に良好な銅メッキが得られた。 しかし,この $\mathrm{pH}$ 付近では導電率が小さく, その上, 銅 析出時に水素の同時発生があれば, 電極近傍の $\mathrm{pH}$ 変化 が考えられるので, 電導塩拈よび緩衝凮として硫酸ナト リウム拉よび硫酸アンモニウムを加えた。これらを加え た場合の $\mathrm{pH}$ 扎よび導電率の変化は第2 表 の通りであ る。

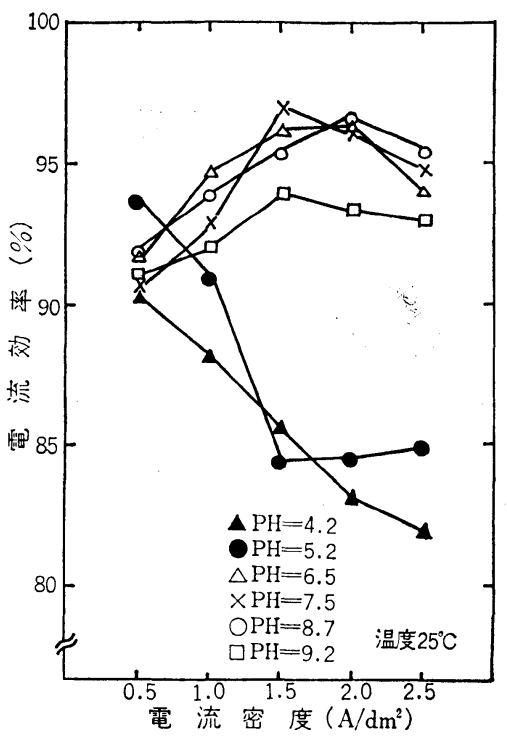

温度 $25^{\circ} \mathrm{C}$

第 8 図電流効率に括よぼす $\mathrm{pH}$ 抢よび電流密 度の影響

組成 $\mathrm{D}$ の溶液について, $\mathrm{pH}$, 電流密度を変觉, 析出 物の光沢, 密着性, 電流効率に扣よぼす影響を調べた。 電解はすべて, $300 \mathrm{~m} l$ ビーカーを用いて液量 $250 \mathrm{~m} l$ で 行ない, 光沢は肉眼, 密着性はメッキ試片を $90^{\circ}$ 折り曲 げ，ハク離しないものを良とした。メッキ試片は $20 \mathrm{~mm}$ $\times 50 \mathrm{~mm}$ に切断した厚サ $1 \mathrm{~mm}$ の軟鋼板を 500 番 エメ リ一紙で研摩したものをアルカリ脱脂して用い, 陽極に は純度 $99.99 \%$ の電解銅を用いた。 $\mathrm{pH}$ 調整は硫酸およ び水酸化ナトリウムで行ない, 電流効率の測定は銀電量 計を用い, 重量法で行なった。なお，均一電着性をハル セル試験でみた。

\section{2-3-1 $\mathrm{pH}$ 扣よび電流密度の影響}

$\mathrm{pH} 3.5$ 以下の容液の電解は, 酸性硫酸銅溶液の電解 とほとんど変わらず,置換反応による銅析出もあって,軟 鋼上に良好な銅メッキは得られなかった。また， $\mathrm{pH} 9.5$ 以上の場合も, 密着性および光沢が悪くなった。よって 電流効率は $\mathrm{pH}$ 4.0 9.2 の範囲で調べた。電流密度括 よび $\mathrm{pH}$ が電流効率におよぼす影響は 第8図 の通りで

第 2 表 添加剂の導電率に括よぼす影響 $\left(25^{\circ} \mathrm{C}\right)$

\begin{tabular}{c|c|c|c|c}
\hline \hline 組 & $\mathrm{A}$ & $\mathrm{B}$ & $\mathrm{C}$ & $\mathrm{D}$ \\
\cline { 2 - 5 } & $\mathrm{CuSO}_{4} \cdot 5 \mathrm{H}_{2} \mathrm{O} 100 \mathrm{~g} / l$ & $\mathrm{~A}+\mathrm{En} 50 \mathrm{~g} / l$ & $\mathrm{~B}+\left(\mathrm{NH}_{4}\right)_{2} \mathrm{SO}_{4} 50 \mathrm{~g} / l$ & $\mathrm{C}+\mathrm{Na}_{2} \mathrm{SO}_{4} \cdot 10 \mathrm{H}_{2} \mathrm{O} 50 \mathrm{~g} / l$ \\
\hline $\mathrm{pH}$ & 3.8 & 11.4 & 9.5 & 9.5 \\
\hline 導電率 $(\mathrm{mho} / \mathrm{cm})$ & $1.4 \times 10^{-2}$ & $3.2 \times 10^{-2}$ & $5.5 \times 10^{-2}$ & $6.7 \times 10^{-2}$ \\
\hline \hline
\end{tabular}


$\mathrm{PH}=7.0$

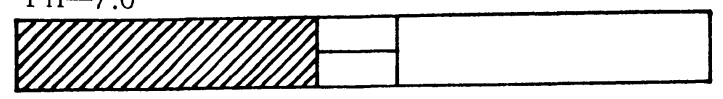

$\mathrm{PH}=9.0$

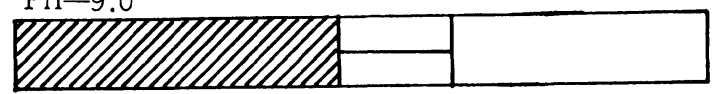

高電流密度

低電流密度—

$\square$ 光沢

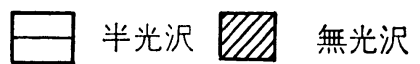

$\mathrm{CuSO}_{4} \cdot 5 \mathrm{H}_{2} \mathrm{O} 100 \mathrm{~g} / l$, En $50 \mathrm{~g} / l, \mathrm{Na}_{2} \mathrm{SO}_{4} \cdot 10 \mathrm{H}_{2} \mathrm{O} 50 \mathrm{~g} / l$, $\left(\mathrm{NH}_{4}\right)_{2} \mathrm{SO}_{4} 50 \mathrm{~g} / l$, 電流 $2 \mathrm{~A}$, 温度 $25^{\circ} \mathrm{C}, 10 \mathrm{~min}$ 間

第 9 図ハルセル試験 A（pH の影響）

ある。 $\mathrm{pH}$ が低い場合は電流密度を大きくすると, 水素 発生があって電流効率は著しく悪くなる。 $\mathrm{pH}$ 6.5 8.7 の溶液からの析出物が光沢, 密着性とも良好であった。 $\mathrm{pH} 7.0$ と $\mathrm{pH} 9.0$ におけるハルセル試験結果は 第9図 の通りで， pH 8.7 を越えると光沢メッキの得られる電 流密度範囲がせまくなる。

\section{2-3-2Ｅn 配合比，温度，硫酸銅濃度の影響}

温度 $25^{\circ} \mathrm{C}$ 扣よび $5^{\circ} \mathrm{C}$ と打いて, 硫酸銅濃度を $100 \mathrm{~g} / l$ と一定にして, En の配合比を增加させた場合の陰極効 率および陽極効率は 第3 表 のとおりで，En の配合比 および温度の変化によって電流効率はほとんぞ影響を受 けない。しかし， 5C に捻いては En 配合比 2.5 まで は，陽極に青色の結晶性付着物を生じ，陽極溶解は部分 的にしか起こらなかった。 $10^{\circ} \mathrm{C}$ 以上では En 配合比 2 でも陽極に付着物は生成せず, $10 \sim 50^{\circ} \mathrm{C}$ の間では, 温度はメッキにほとんど影響を扣よぼさなかった。50ํ を超えるとメッキの光沢が悪くなった。En 配合比は 3 以上にすると $5^{\circ} \mathrm{C}$ でも電解時の陽極付着物はなくなる が,第10図からわかるとおり，配合比增加とともに光沢 メ ッキが得られる電流密度範囲が狭くなる。したがって経 済的な面も考虑するとき，En の配合比は 2 をやや越え る程度とし, 温度を $10 \sim 50^{\circ} \mathrm{C}$ にして電解すればよいこ
配合比 2

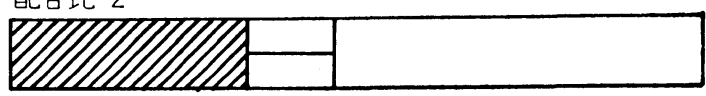

配合比 3

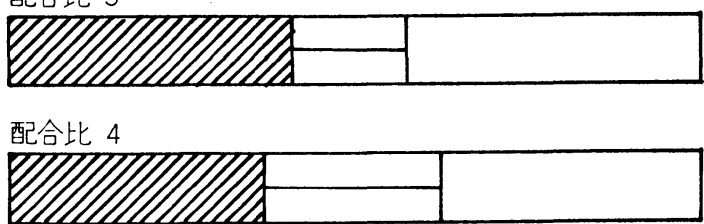

配合比 5

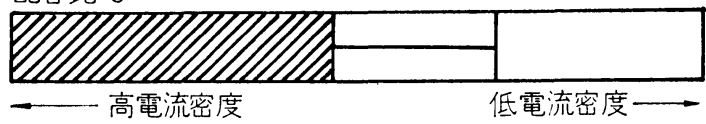

第 9 四の組成でEnの嶩度たけを変化させたるの $\mathrm{pH}=8.0$, 電流 $2 \mathrm{~A}$, 温度 $25^{\circ} \mathrm{C}, 10 \mathrm{~min}$ 間

\section{第10図 ハルセル試験 B（配合比の影響）}

とになる。

En 配合比を 2 とした場合の硫酸銅濃度は $0.3 \mathrm{~mol} /{ }^{l}$ 以下にすると, 適正電流密度が小さくなり, $0.5 \mathrm{~mol} / l$ 以上では, 夜間冷却されると結晶性の沈殿を生じるの で, 硫酸銅濃度は $0.3 \sim 0.5 \mathrm{~mol} / l$ が適当である。

\section{3. 考察}

硫酸銅に En を加えると平衡電位, 析出電位とも負方 向にずれるが，良好な銅メッキが得られる電流密度 1.5 $\sim 2.5 \mathrm{~A} / \mathrm{dm}^{2}$ では分極が数 $100 \mathrm{mV}$ に達する。とくに $\mathrm{pH}$ の増加とともに分極の増加（第 6 図参照）する原因 について N.V. Osetrova は, En の電極面への吸着が $\mathrm{pH}$ の上䄯とともに増加するためで，また塩素イオンが 存在すると, En の強い吸着を妨げ, 銅析出に対して触 媒的に作用するため分極が小さく，2.6A/dm² $75 \mathrm{mV}$ であると述べている9)。確かに塩化銅を用いた方が分極 は小さいが（第 6 図と第 7 図 比較参照） $100 \mathrm{mV}$ 以下に はならなかった。いずれにしても，[CuEn] $]^{2+}$ キレート からの銅析出に際しては二重層通過過程に大きな抵抗が

第3 表 En 配合比括よび温度の電流效率飞抢よ住す影整

$\mathrm{CuSO}_{4} \cdot 5 \mathrm{H}_{2} \mathrm{O} 100 \mathrm{~g} / l, \mathrm{Na}_{2} \mathrm{SO}_{4} \cdot 10 \mathrm{H}_{2} \mathrm{O} 50 \mathrm{~g} / l,\left(\mathrm{NH}_{4}\right)_{2} \mathrm{SO}_{4} 50 \mathrm{~g} / l \mathrm{pH} 8.0$, 陰極電流密度 $2 \mathrm{~A} / \mathrm{dm}^{2}$, 陰極面積 : 陽極面積 $=1: 2$

\begin{tabular}{|c|c|c|c|c|c|c|c|}
\hline 温度 $\left({ }^{\circ} \mathrm{C}\right)$ & $\begin{array}{r}\text { En 配 } \\
\text { 電流効率 }(\%) \\
\end{array}$ & mol比) & 2 & 2.5 & 3 & 4 & 5 \\
\hline \multirow{2}{*}{25} & 陰 & 極 & 96.6 & 94.3 & 95.7 & 95.9 & 96.4 \\
\hline & 陽 & 極 & 102.1 & 102.5 & 102.7 & 101.3 & 105.1 \\
\hline \multirow{2}{*}{5} & 陰 & 極 & 94.1 & 95.4 & 95.1 & 91.5 & 91.4 \\
\hline & 陽 & 極 & 103.0 & 100.1 & 100.9 & 96.1 & 103.0 \\
\hline
\end{tabular}


あることがうかがわれる。

H.A. Laitinen らも, 水銀電極上への析出に際して, アンモニア，ピリジン，チオシアンあるいは塩素の 2 価 の銅錯イオンは, まず1価の銅錯イオンとなって還元さ

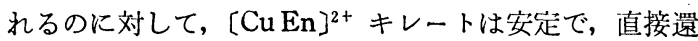
元されることを示している ${ }^{10)}$ 。著者らも定電位法によっ て放電イオン種の決定を行ない, 析出機構を検討した が，詳練は別の機会に報告する。

また文献では陽極の不㗢態化が 述べられているが9， 本実験では $10^{\circ} \mathrm{C}$ 以下の低温でない限り, 陽極に付着物

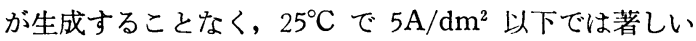
不働態化は観察されなかった。

硫酸ナトリウム技よび硫酸アンモニウムはとくに加え なくても良好なメッキが得られたが，硫酸アンモニウム を含まない電解液は，長期間使用すると光沢あるメッキ が得られなくなった。これは硫酸アンモニウムが緩衝作 用をもつためと考えられる。

軟鋼上に得られる銅メッキを $\mathrm{En}$ キレート電解液と, シアン錯塩電解液とで比較してみると, En キレート電 解液は均一電着性の面でやや劣るが, 密着性は差がな く, 光沢は著しくすぐれている。また電解に際して, カ クハンの必要もなく, 適正電流密度も大きいので, シア ン錯塩浴に代えて実用しらる性能を十分に持っていると 考えられる。

\section{4. 結 論}

銅イオン (II) と En とからなるキレートについて, その $\mathrm{pH}$ 依存性を調べたところ， $\mathrm{pH} 3.5 〜 5.5$ の範团 で, $[\mathrm{CuEn}]^{2+} \mathrm{pH} 6.0$ 以上で $\left[\mathrm{CuEn}_{2}\right]^{2+}$ のキレートを 生成し， pH 5.5 6.0 ではこの両者が共存することが わかった。

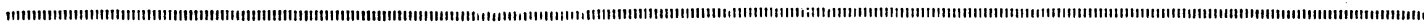

このキレート浴液を用いて軟鋼上に銅メッキを行なっ た結果, 光沢があり, 密着性の良好なメッキが得られる 条件は次の通りで,

$\begin{array}{lc}\mathrm{CuSO}_{4} \cdot 5 \mathrm{H}_{2} \mathrm{O} & 75 \sim 125 \mathrm{~g} / l \\ \mathrm{En} & 40 \sim 65 " \\ \mathrm{Na}_{2} \mathrm{SO}_{4} \cdot 10 \mathrm{H}_{2} \mathrm{O} & 50 " \prime \\ \left(\mathrm{NH}_{4}\right)_{2} \mathrm{SO}_{4} & 50 " \prime \\ \mathrm{pH} & 6.5 \sim 8.7 \\ \text { 温 度 } & 10 \sim 50^{\circ} \mathrm{C} \\ \text { 陰極電流密度 } & 1.5 \sim 2.5 \mathrm{~A} / \mathrm{dm}^{2}\end{array}$

この条件内では, 電流效率は95\%以上であった。 (1969-2-7 受理)

\section{文献}

1) 乾, 細川, 羽島, 本誌, 18, 430 (1967)

2) 乾, 細川, 丹生, 同上, 19,83 (1968)

3）たとえば, N.V. Osetrova, P.C. Titov, NDVSH, Khimiya i Khim. Teknologiya 4, 782 (1958)

4）たとえば N. V. Gudin, Chem. Abst., 61, 2718d (1964)

5) J. Bjerrum, E.T. Neilson, Acta Chem. Scand., 2, 307 (1948)

6) A. Werner, Z. anorg. Chemie, 21, 41 (1899)

7 ) G.A. Carlson, J.P. McReynolds, F. H. Verhoek, J. Am. Chem. Soc., 67, 1334 (1945)

8) H. B. Jonassen, T. H. Dexter, ibid, 71, 1553 (1949)

9) N. V. Osetrova, P. C. Titov, Izvest. Vysshikh. Ucheb. Zavedenii, Tsvetnaya Met., 3, 154 (1960)

10) H. A. Laitinen, E. L. Onstott, J. C. Bailar, Jr., S. Swan, Jr., J. Am. Chem. Soc., 71, 1550 (1949)

\section{塗料・プラスチックス・コムのウェザリンクに関する規格資料類集}

\section{第 2 集 $(1964 \sim 1966)$ 発 行}

このたび，本会有機皮膜部会では同部会資料小委員会 の編集により「塗料・ブラスチックス・ゴムのウェザリ ングに関する規格資料類集」第 2 集を発行いたしまし た。

この類集には，有機皮膜材料のウェザリングに関する 世界各国の文献・規格・資料について抄録したもので, 関係各位にはたいへんお役に立つるのと確信しておりま す。な括，発行部数に限りがありますので，入手こ希望 の向きは下記様式にて，代金を添えて至急拈申し込み下 さい。
体 裁 タイブオフセット印刷（9ポイント）

B 5 版 約 170 ベーシ

頒価 1 部 2,000円 (送料共)

発 行 者 金属表面技術協会・有機皮膜部会

申込方法 氏名, 送付先を明記の上, 代金を添えてお申 し込み下さい。

※電話・ハガキなどによる申込はご遠虑下さ い。

申 込 先 東京都千代田区神田岩本町 2 共同ビル 金属表面技術協会 有機皮膜部会 